\title{
Static and dynamic measurement and computer simulation of diabetic mellitus foot biomechanics
}

\author{
D. Bubanja ${ }^{1 *}$, A. Djukic ${ }^{1}$, A. Jurisic-Skevin ${ }^{1}$, V. Grbovic ${ }^{1}$, I. Saveljic ${ }^{2}$, T. Exarchos ${ }^{3}$, \\ N.Filipovic ${ }^{2}$
}

${ }^{1}$ Faculty of Medical Science, University of Kragujevac, Serbia

${ }^{2}$ Faculty of Engineering, University of Kragujevac, Serbia

${ }^{3}$ University of Ioannina, Greece

* Corresponding author

\begin{abstract}
The objective of this study was to evaluate static and dynamic results on the foot pressure measurement and computer simulation for diabetes mellitus patients. The finite element analysis was used to compare with pressure foot measurement. The foot and ankle model consisted of 28 bony segments is created from DICOM CT slice from specific patient with diabetes mellitus diagnosis. All material properties are considered as homogeneous, isotropic and linearly elastic. Foot pressure measurement for both static and dynamic condition gave topographic distribution of high pressure points which is in correlation with clinical tests results. The result for maximum pressure measurement of the left foot $124.74 \mathrm{kPa}$ is in good comparison with finite element results for $121 \mathrm{kPa}$. It looks that numerical simulation in combination with foot pressure measurement device can be efficient and inexpensive screening tool, which could go in direction for prevention of the diabetic foot complications, associated with high mortality and morbidity that has significant economic impact on healthcare system.
\end{abstract}

Keywords: Foot pressure measurement; Diabetes mellitus patient, Finite element analysis.

\section{Introduction}

Diabetes mellitus is chronic disease with insidious beginning, without specific symptoms, which leads to late diagnosis, most often when complications have already taken place. There were 366 million patients with diabetes in year 2011, worldwide, of which 4.6 million died. There were 630000 patients with diabetes mellitus in year 2010, which constitutes $8.6 \%$ of Serbian population. It is estimated that $10.2 \%$ of Serbian population will be diabetic in the year 2030 (Diabetes -The Policy Puzzle, www.batut.org.rs).

During its course diabetes mellitus leads to chronic microvascular and macrovascular complications. Bad glycoregulation, obesity, dislidemia, duration of disease and smoking contribute to occurrence of these complications. Microvascular complications are: diabetic neuropathy, nephropathy and retinopathy. Macrovascular complications are: heart attack, stroke and peripheral vascular disease. Clinical entity characterized with nerve damage during diabetes mellitus is called diabetic neuropathy. Together with vascular damage on lower extremities it is most common cause of diabetic foot. Ischemic foot without neuropathy is rarely seen in diabetic 
patients, and treatment is same as for neuroischemic foot. Patients with diabetes mellitus during life have 15 to $25 \%$ chance to develop plantar foot ulcer. Most of them (50 to70\%) will have recurrence of ulcer in next five years. This condition leads to foot amputation in $85 \%$ of cases (Bulton 2008). Mortality rate after foot amputation due to diabetic foot is 13 to $40 \%$ in firs year, 35 to $65 \%$ in three year period, and 39 to $80 \%$ in five years which is significantly higher than in most of malignancy.

It is very difficult to directly measure the stress and deformation inside the foot biomechanics in vivo. In order to provide a supplement to the experimental inadequacy, many researchers had turned to the computational methods in search of more clinical information. Computational modeling, such as the finite element (FE) method has been used increasingly in many biomechanical investigations with great success due to its capability of modeling structures with irregular geometry and complex material properties, and the ease of simulating complicated boundary and loading conditions in both static and dynamic analyses. The FE analyses could allow efficient parametric evaluations for the outcomes of the shape modifications and other design parameters of footwear without the prerequisite of fabricated footwear and replicating patient trials.

Existing FE models of the foot or footwear in the literature (Bandak et al 2001, Chen et al 2003. Giddings et al 2000, Lemon et a 1997, Syngellakis et al 2000, Verdejo and Mills 2004) were developed under certain simplifications and assumptions such as a simplified or partial foot shape, assumptions of linear material properties, infinitesimal deformation and linear boundary conditions without considering friction and slip. Although several 3D foot models were developed recently to study the biomechanical behavior of the human foot and ankle, a comparison with foot pressure measurement has not been reported.

In this paper we firstly described finite element formulation, mesh generation procedure, material properties, boundary condition and clinical setup measurement for foot pressure for static and dynamic condition. Then some results for measurement for both static and dynamic condition are presented as well as numerical results for static condition. At the end some conclusions are given.

\section{Methods}

\subsection{Finite element formulation}

We used linear tetrahedron finite element (Fig. 1) where displacement field over the tetrahedron element is defined by the three components $u_{x}, u_{y}$ and $u_{z}$. These displacements are linearly interpolated over the element from their nodal values

$$
\left[\begin{array}{l}
u_{1} \\
u_{2} \\
u_{3}
\end{array}\right]=\left[\begin{array}{llll}
u_{11} & u_{12} & u_{13} & u_{14} \\
u_{21} & u_{22} & u_{23} & u_{24} \\
u_{31} & u_{32} & u_{33} & u_{34}
\end{array}\right]\left[\begin{array}{l}
N_{1} \\
N_{2} \\
N_{3} \\
N_{4}
\end{array}\right]
$$

where N1, N2, N3, N4 are the interpolation functions which are simply the tetrahedral coordinates; and $\mathrm{u} 11, \ldots, \mathrm{u} 34$ are the nodal displacements. 


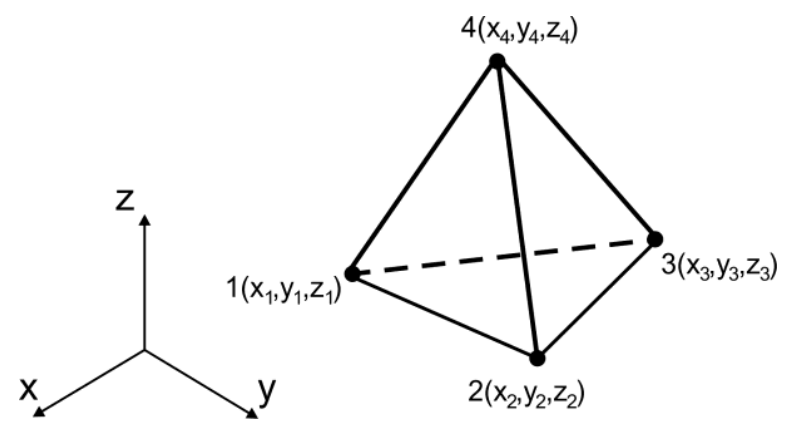

Fig. 1 The linear tetrahedron element

The internal virtual work can be expressed as (Kojic et al 2008)

$$
\delta W^{\text {int }}=\int_{V} \delta \mathbf{e}^{T} \boldsymbol{\sigma} d V=\delta \mathbf{U}^{T} \int_{V} \mathbf{B}^{T} \mathbf{C B} d V \mathbf{U}=\delta \mathbf{U}^{T} \mathbf{K} \mathbf{U}
$$

where we have employed the relation for strain components:

$$
\mathbf{e}=\left\{\begin{array}{c}
e_{x x} \\
e_{y y} \\
e_{z z} \\
\gamma_{x y} \\
\gamma_{y z} \\
\gamma_{z x}
\end{array}\right\}=\left\{\begin{array}{c}
u_{1,1} \\
u_{2,2} \\
u_{3,3} \\
u_{1,2}+u_{2,1} \\
u_{2,3}+u_{3,2} \\
u_{1,3}+u_{3,1}
\end{array}\right\}=\left[\begin{array}{ccccccc}
N_{1,1} & 0 & 0 & \ldots & N_{N, 1} & 0 & 0 \\
0 & N_{1,2} & 0 & \ldots & 0 & N_{N, 2} & 0 \\
0 & 0 & N_{1,3} & \ldots & 0 & 0 & N_{N, 3} \\
N_{1,2} & N_{1,1} & 0 & \ldots & N_{N, 2} & N_{N, 1} & 0 \\
0 & N_{1,3} & N_{1,2} & \ldots & 0 & N_{N, 3} & N_{N, 2} \\
N_{1,3} & 0 & N_{1,1} & \ldots & N_{N, 3} & 0 & N_{N, 1}
\end{array}\right]\left\{\begin{array}{c}
U_{1}^{1} \\
U_{2}^{1} \\
U_{3}^{1} \\
\vdots \\
U_{1}^{N} \\
U_{2}^{N} \\
U_{3}^{N}
\end{array}\right\}=\mathbf{B} \mathbf{U}
$$

from which $\delta \mathbf{e}^{T}=\delta \mathbf{U}^{T} \mathbf{B}^{T}$, and the constitutive relationship $\boldsymbol{\sigma}=\mathbf{C e}$; here, $\mathbf{e}$ is the strain (used here in th form of the engineering strain vector), $\mathbf{U}$ is the vector of nodal displacements, $\mathbf{B}$ is the strain-displacement relation matrix, and $\mathbf{C}$ the material constitutive matrix. Clearly, the stiffness matrix $\mathbf{K}$ is

$$
\mathbf{K}=\int_{V} \mathbf{B}^{T} \mathbf{C B} d V
$$

and the element internal force $\mathbf{F}^{\text {int }}$ is given by the expression $\mathbf{F}^{\text {int }}=\mathbf{K U}$. The stiffness matrix is symmetric and has dimensions $3 N \times 3 N$ (in our case $12 \times 12$ ) and the force vector $\mathbf{F}^{\text {int }}$ is of size $3 N, \mathbf{F}^{\mathrm{int}}\left(F_{x}^{(\mathrm{int}) 1}, F_{y}^{(\mathrm{int}) 1}, F_{z}^{(\mathrm{int}) 1}, \ldots . ., F_{x}{ }^{(\mathrm{int})}, F_{y}{ }^{(\mathrm{int})}, F_{z}{ }^{(\mathrm{int})}\right)$.

The external nodal forces resulting from the pressure on an element surface are calculated by employing again the equivalence of virtual work. A simple approximation for the 4-node tetrahedron element is to calculate the total force as $F_{p}=p A$ (where $p$ is the mean pressure and $A$ is the area of the element side) and use $F_{p} / 3$ at each node in the normal surface direction.

\subsection{Mesh generation}

The FE model of the human foot and ankle, as shown in Fig. 2, consisted of 28 bony segments, including the distal segments of the tibia and fibula and 26 foot bones: talus, calcaneus, cuboid, navicular, 3 cuneiforms, 5 metatarsals and 14 components of the phalanges. 
We created a 3D FE model by using MIMICS software 3D DICOM CT slices (Fig. 2a). After smoothing of the surface boundary the final tetrahedral finite element mesh is generated. The finite element analysis was performed with program PAK (Kojic et al 1998). The finite element mesh was composed of 48447 nodes and 232187 linear tetrahedral elements.
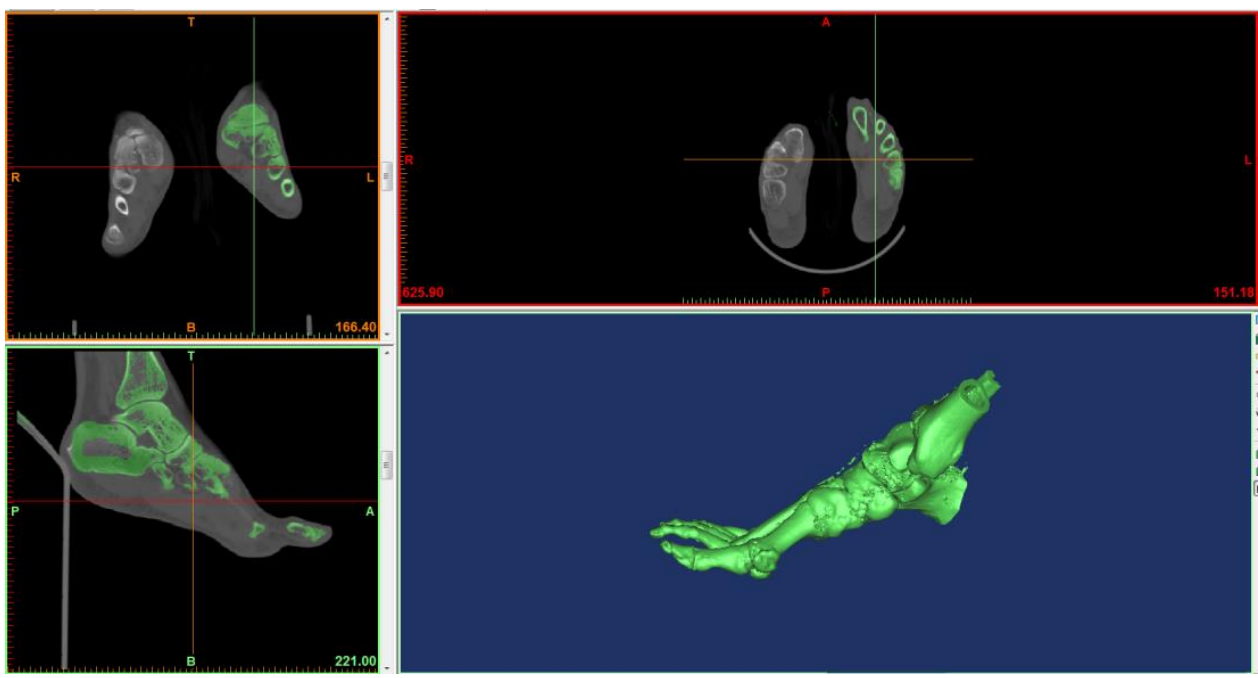

Fig. 2 3D foot reconstruction from DICOM CT slices

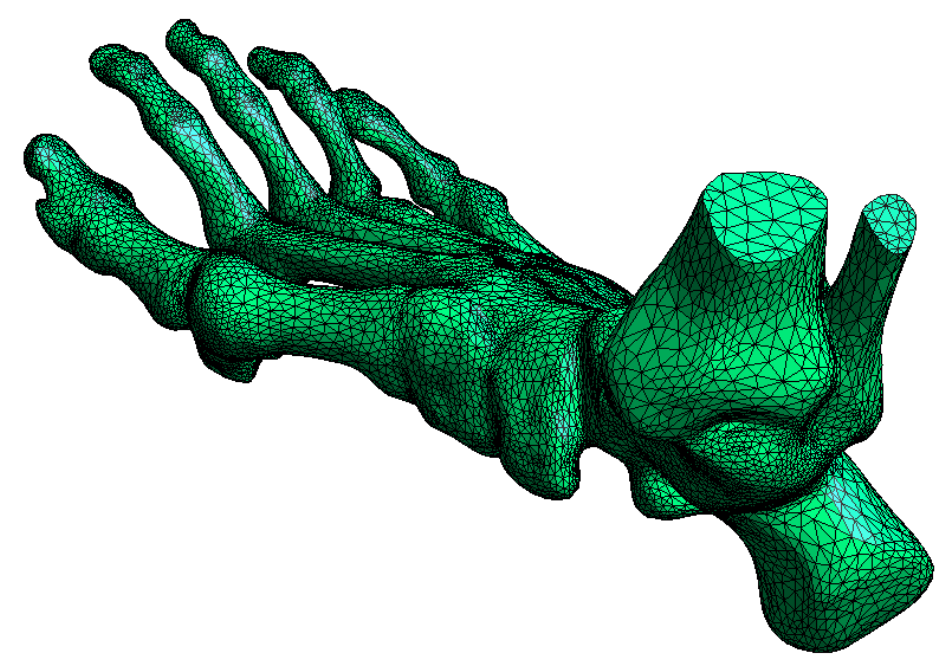

Fig. 3 3D finite element mesh of foot model after generation and smoothing techniques

\subsection{Material properties and boundary conditions}

We consider all material properties as homogeneous, isotropic and linearly elastic. The effective Young's modulus and Poisson's ratio for the bony structures were assigned as $7300 \mathrm{MPa}$ and 0.3 , respectively, according to the model developed by Nakamura et al 1981. The Young's modulus of the cartilage is $1 \mathrm{MPa}$ (Athanasiou et al 1998) and the plantar fascia (Wright and 
Rennels 1964) was selected from the literature. The cartilage was assigned with a Poisson's ratio of 0.4 for its nearly incompressible nature.

The load of half body weight $400 \mathrm{~N}$ was applied as it is presented in Fig 4. The plate which simulated foot pressure sensor was fixed as it is shown in Fig 4.

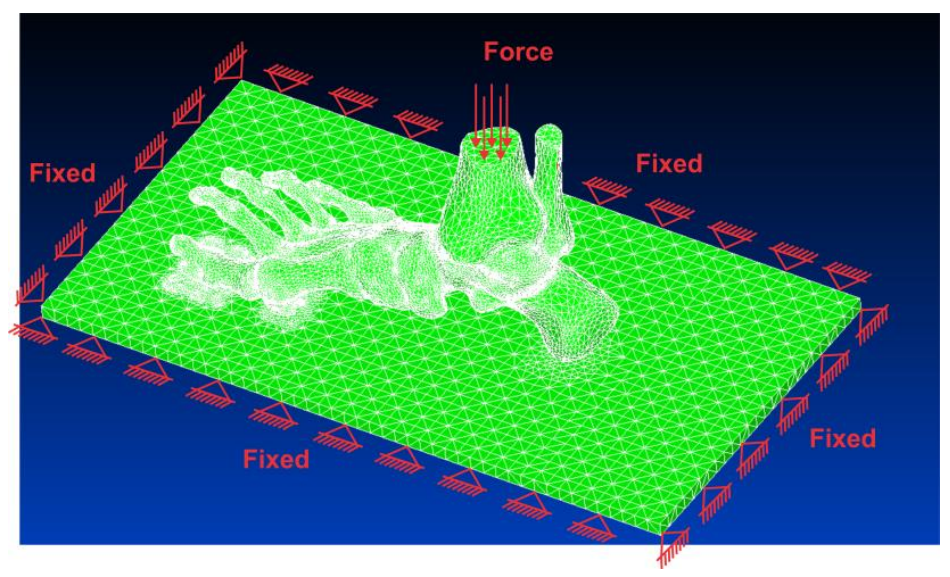

Fig 4. Loading of $400 \mathrm{~N}$ and fixed boundary condition

\subsection{Clinical setup}

We present a case of 63 year old male patient with diabetes mellitus. Main complaints were numbness in the feet, weakness in the legs and night pain in legs. He was diagnosed with diabetes at age 48 , and was treated with oral antidiabetics until six years ago when he started insulin therapy in two daily doses, which was intensified after 3 months due to bad glycoregulation (HbA1C-9\%). At the same time diabetic polyneuropathy was diagnosed on electromyiographic examination. Diabetic foot infection led to amputation of second toe on the left foot later that year. Recovery period and wound healing went uneventful. Since then he is on intensified therapy on four daily doses of human insulin. He is non-smoker and has hypertension and dyslipidemia. Other possible causes of neuropathy such as vitamin b12 deficiency, thyroid dysfunction, and alcohol abuse were excluded. Paitent has BMI $23,93 \mathrm{~kg} / \mathrm{m} 2$, arterial blood pressure $140 / 95 \mathrm{mmHg}$, hearth rate 78/minute. His A1c is 7,3\%, FBG 3,9-6.9mM, PPG 3.7-9.6mM, CCr 0.96ml/min, Esbach 0.24g/d, TSH 1.7, CRP 0.6. Both lower extremities are present. Peripheral arterial pulses are present on both feet. Skin was warm and dry. At the left foot second toe is absent. There is hallux valgus deformity (bunion) of the left foot. At both feet there are calluses. Using both feet ten point, nylon Semmes-Weinstein monofilament tests we found inability to perceive 10 grams of force in points MT1, MT5, as well as in the first and third toe of the left foot. Vibratory sensation was examined using tuning fork and found abnormal on both lateral malleolus. Computerized tomography of both feet shows osteoporosis of metatarsal bones, and marked hallux valgus deformity of the left foot. Static and dynamic measurement of plantar load distribution for each foot was conducted using pressure platform system.

Schematic foot pressure measurement procedure is presented in Fig. 5. 


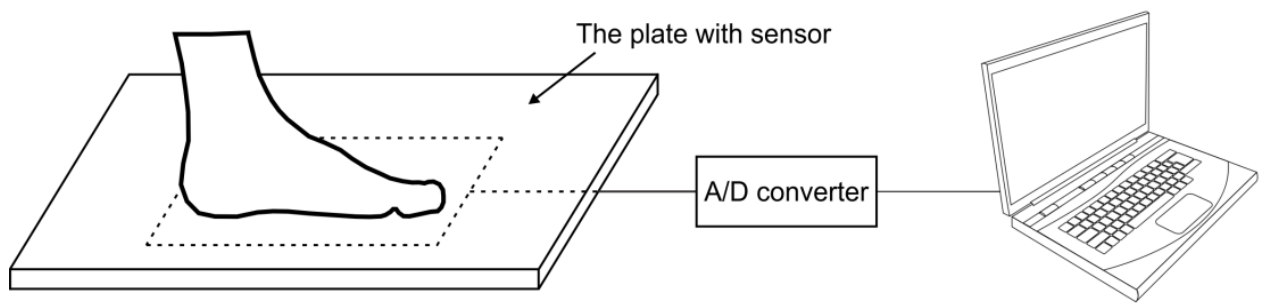

Fig. 5 Foot pressure measurement procedure

\section{Results}

\subsection{Measurements}

Static plantar load measurement is performed in following manner: before measuring for five seconds patient stands on platform barefooted, and then load is measured. Procedure is repeated three times. The foot was divided into 10 regions: heel, mid-foot, first, second, third, fourth and fifth metatarsal (MT) heads, hallux, second toe and third to fifth toes.

Results for left foot: max.124.74 kPa; MT max.118.63 kPa min $3.96 \mathrm{kPa}$; heel max.19.8 $\mathrm{kPpa} \min .5 .61 \mathrm{kPa}$ are presented in Fig. 6. For the right foot measured values are: max.47.76 $\mathrm{kPa}$; MTmax.47.8 kPa min.6.49 kPa; heel max.13.11 kPa min.3.49 kPa. For dynamic plantar load measurement the patient is standing one meter from platform. Then he starts walking with left foot first, and on the third step he stands barefooted on the platform with his left foot and keeps walking. After that the same measurement procedure is performed for the right foot. Device automatically measures load distribution changes in real time in three dimensions. Results are given both numerically and graphically. The results for left and right foot are presented in Fig. 7: left foot: MT(3) $\max 137.78 \mathrm{kPa}$ heel max $26.82 \mathrm{kPa}$; right foot: MT(5) $\max 146 \mathrm{kPa}$, heel max.24.62 kPa. For dynamic plantar measurements for left and right foot the results have been shown in Fig 8: left foot max.137,78 kPa, rearfoot max $26.82 \mathrm{kPa}$; right foot: max. $146 \mathrm{kPa}$, rearfoot max $24.62 \mathrm{kPa}$;

Effective stress distribution along plate for right and left foot are presented in the Figs 9,10 respectively.

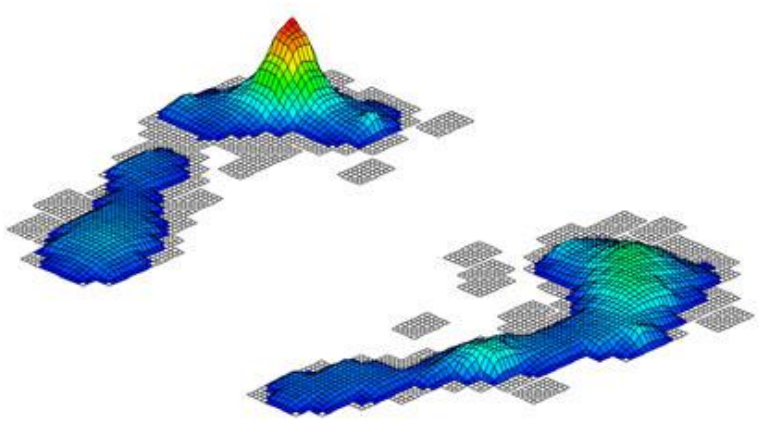

Fig 6. Results for static plantar measurements for left foot: max.124.74kPa; MT max.118.63 $\mathrm{kPa} \min 3.96 \mathrm{kPa}$; heel max.19.8 kPa min.5.61kPa. 

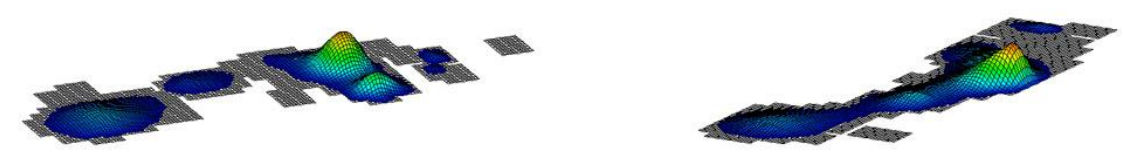

Fig 7. Results for dynamic plantar measurements for left and right foot: max.145.16 kPa for left foot and max. $156.98 \mathrm{kPa}$ for right foot;
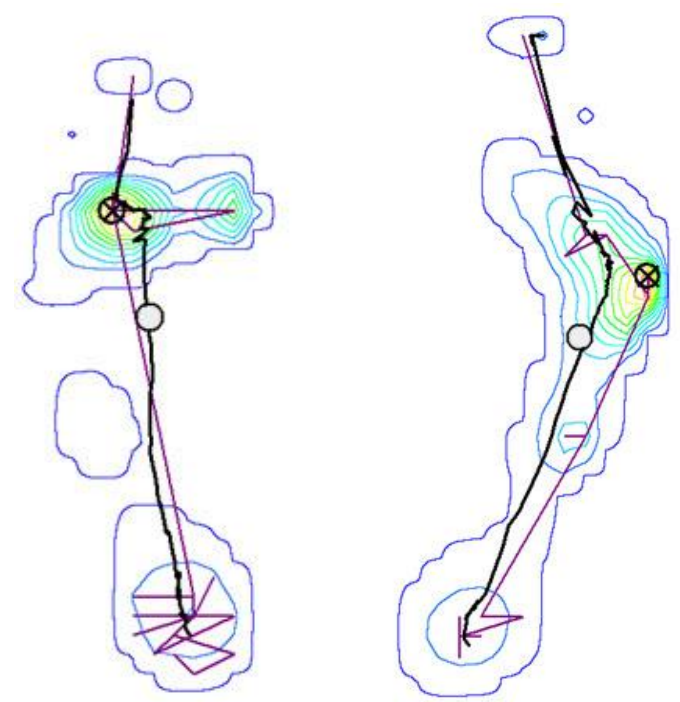

Fig 8. Results for dynamic plantar measurements for left and right foot: left foot max.137,78 $\mathrm{kPa}$, rearfoot max $26.82 \mathrm{kPa}$; right foot: $\max .146 \mathrm{kPa}$, rearfoot $\max 24.62 \mathrm{kPa}$; 


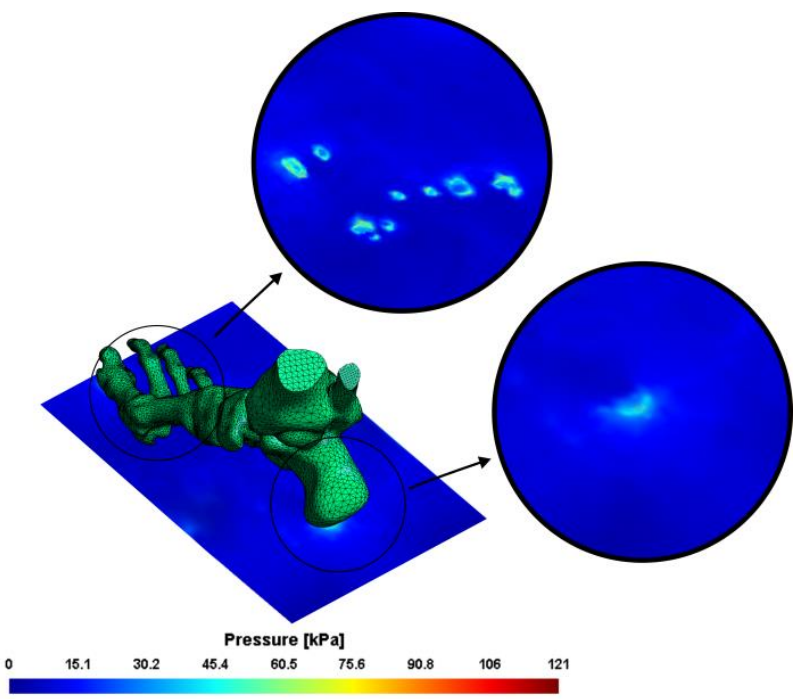

Fig 9. Effective stress distribution along plate for right foot

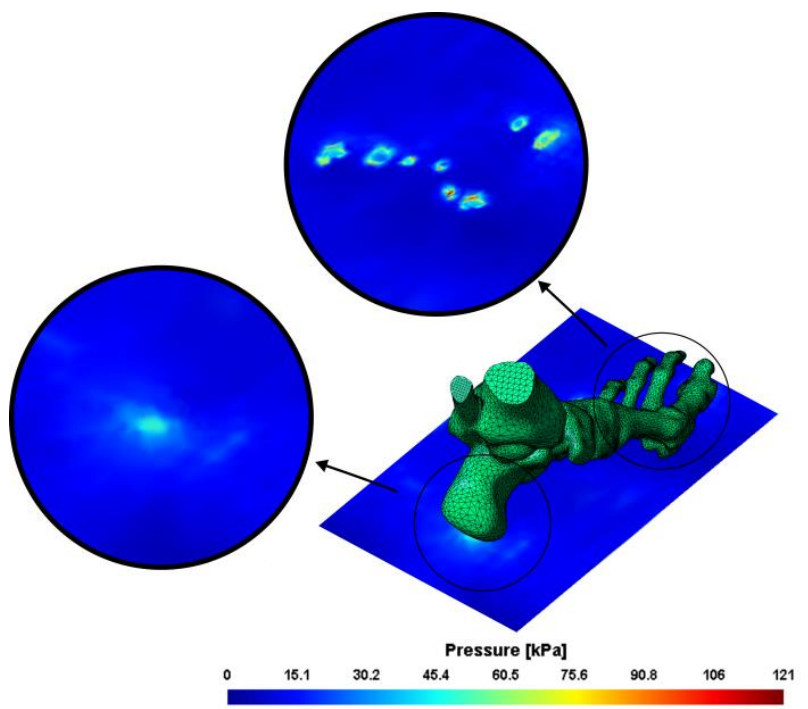

Fig 10. Effective stress distribution along plate for left foot

\section{Conclusions}

Numerous studies concluded that high plantar pressure, duration of diabetes mellitus longer than ten years, inadequate glycoreguation, foot deformation, male gender, one or more signs of diabetic neuropathy are significantly associated with foot ulcer occurrence (Lazaro et al 2011, Somai and Vogelgesang 2011, Singh et al 2005). In study Lavery et al 1998, 78\% of patients with diabetic foot ulcer had some kind of foot deformity which was directly correlated with ulcer localization and maximum plantar pressure point. Vascular disease, nephropathy, retinopathy, obesity and level of education were not connected with foot ulcers (Lavery et al 
2003). In prospective cohort studies using EMED pressure platform, a maximum barefoot dynamic pressure of $87.5 \mathrm{~N} / \mathrm{cm} 2$ had sensitivity of $64 \%$ and specifity of $46 \%$, positive predictive value of $17 \%$, and negative predictive value of $90 \%$ [19].

In our report results of both static and dynamic measurement of plantar pressure gave topographic distribution of high pressure points which is in correlation with clinical tests results. Static and dynamic results also correlated between each other.

Using dynamic foot pressure measuring, monofilament test and vibration fork test we can pinpoint location with highest risk of developing diabetic foot ulcer. Dynamic pressure measuring is not time consuming, and data obtained during examination are in digital form which makes them easily available and comparable.

Numerical simulation gave for static loading $121 \mathrm{kPa}$ which is in good comparison with $124.74 \mathrm{kPa}$ of foot pressure measurement. This can be efficient and inexpensive screening tool, which could give us a chance to prevent diabetic foot complications, associated with high mortality and morbidity that has significant economic impact on healthcare system.

Acknowledgements This paper is supported by Ministry of Education, Science and Technological Development of the Republic of Serbia (projects number III41007 and ON 174028).

\section{Извод}

\section{Статичко и динамичко мерење и компјутерска симулација биомеханике стопала код пацијента ca diabetic mellitus дијагнозом}

\section{Bubanja ${ }^{1^{*}}$, A. Djukic ${ }^{1}$, A. Jurisic-Skevin ${ }^{1}$, V. Grbovic ${ }^{1}$, I. Saveljic ${ }^{2}$, T. Exarchos ${ }^{3}$, N.Filipovic ${ }^{2}$}

${ }^{1}$ Факултет медицинских наука, Универзитет у Крагујевцу, Србија

${ }^{2}$ Факултет инжењерских наука, Универзитет у Крагујевцу, Србија

${ }^{3}$ University of Ioannina, Greece

* Главни аутор

\section{Резиме}

Циљ ове студије је процена резултата мерења и компјутерске симулације статичких и динамичких оптерећења стопала код пацијента са дијагнозом diabetes mellitus. Метод коначних елемената је коришћен за поређење са мерењима притиска добијених приликом оптерећења стопала. Модел стопала и чланка се састоји од 28 сегмената костију који су добијени ЗД реконструкцијом ДИКОМ ЦТ слика са пацијента код кога је дијагностициран diabetes mellitus. Све материјалне карактеристике су анализиране као хомогене, изотропне и линеарно еластичне. Мерења притиска при статичком и динамичком режиму су дала топографичку дистрибуцију високих зона притиска што је у корелацији са клиничким тестовима.

Мерењем добијени највећи притисак на левом стопалу од $124.74 \mathrm{kPa}$ је упоредив са нумерички добијеним притиском од $121 \mathrm{kPa}$. Закључујемо да нумеричка симулација у комбинацији са мерењима оптерећења стопала може бити ефикасан и јефтин алат у праћењу пацијента и унапређивању превенције код пацијента са дијабетесом стопала што 
може значајно смањити смртност ових пацијената и имати значајан економски ефекат на здравствени систем.

Keywords: Мерење притиска стопала; Diabetes mellitus пацијент, Метод коначних елемената.

\section{References}

Athanasiou, K.A., Liu, G.T., Lavery, L.A., Lanctot, D.R., Schenck, R.C. (1998). Biomechanical topography of human articular cartilage in the first metatarsophalangeal joint, Clinical orthopaedics, vol. 348, pp. 269-281.

Bandak, F.A., Tannous, R.E., Toridis, T. (2001). On the development of an osseo-ligamentous finite element model of the human ankle joint, International Journal of Solids and Structures, vol. 38, pp. 1681-1697.

Bulton AN (2008). The diabetic foot: grand overview,epidemiology and pathogenesis. Diabetes Metab Res Rev;24 (suppl1):s3

Chen, W.P., Ju, C.W., Tang, F.T. (2003) Effects of total contact insoles on the plantar stress redistribution: a finite element analysis, Clinical Biomechanics, Vol. 18, pp. S17-24.

Diabetes -The Policy Puzzle. www.batut.org.rs

Giddings, V.L., Beaupre, G.S., Whalen, R.T., Carter, D.R. (2000). Calcaneal loading during walking and running, Medicine and science in sports and exercise, vol. 32, pp. 627-634.

Kojic M, Slavkovic R, Zivkovic M, Grujovic N, Filipovic N, (1998) PAK - Program for finite element analysis of construction, Faculty of Mechanical Engineering, University of Kragujevac, 34000 Kragujevac.

Kojic, M. Filipovic, N., Stojanovic, B., Kojic N., (2008) Computer Modeling in Bioengineering - Theoretical Background, Examples and Software, J. Wiley \& Sons.

Lavery LA, Armstrong DG, Wunderlich RP, Tredwell JL, Boulton AJM (2003). Predictive value of foot pressure assessment as part of a population-based diabetes disease management program. Diabetes Care.;26:3333-3341.

Lavery LA, David G. Armstrong, Steven A. Vela et Jon G. Fleischli (1998). Practical Criteria for screening patients at high risk for Diabetic foot Ulceration. Arch Intern Med. Jan 26;158(2):157-62.

Lazaro IL, Martinez, FJ. Aragon-Sanchez, J.V. Beneit-Montesions, et al. (2011), Foot biomechanics in patients with diabetes mellitus, Journal of the American Podiatric Association 101,208-214.

Lemmon, D., Shiang, T.Y., Hashmi, A., Ulbrecht, J.S., Cavanagh, P.R. (1997). The effect of insoles in therapeutic footwear: a finite-element approach, Journal of Biomechanics, vol. 30, pp. 615-620.

Nakamura, S., Crowninshield, R.D., Cooper, R.R. (1981). An analysis of soft tissue loading in the foot-a preliminary report, Bulletin of prosthetics research, vol. 18, pp. 27-34.

Singh NI, Amstrong DG, Lipsky BG (2005). Preventing foot ulcers in patients with diabetes JAMA, vol 293, No2.

Somai P, S Vogelgesang (2011). Limited joint mobility in diabetes mellus: the clinical implications. The Journal of Musculoskeletal Medicine 28, 118-124.

Syngellakis, S., Arnold, M.A. and Rassoulian, H. (2000). Assessment of the non-linear behaviour of plastic ankle foot orthoses by the finite element method, Proceedings of the Institution of Mechanical Engineers. Part H, Journal of Engineering in Medicine, vol. 214, pp. 527-539. 
Verdejo, R., Mills, N.J. (2004). Heel-shoe interactions and the durability of EVA foam runningshoe midsoles, Journal of Biomechanics, vol. 37, pp. 1379-1386.

Wright, D., Rennels, D. (1964). A study of the elastic properties of plantar fascia, The Journal of bone and joint surgery. American volume vol. 46, pp. 482-492. 